\title{
Research on Postmodern Music Culture and Vocal Art
}

\author{
Tao Liu
}

Art College, Xiamen University, Xiamen, 361005, China

Keywords: Postmodern music culture, Postmodern context, Vocal art

\begin{abstract}
The experience of vocal music appreciation is diverse, and the feeling difference comes from various states of mind, culture accomplishment, way of thinking and values. Whether people understand or not, postmodernism, as a trend of thought, has permeated today's society, affecting many aspects of life. Deconstruction, collage, disorder and no-center have brought new and anti-traditional concepts and experiences to the music culture, especially the vocal art.
\end{abstract}

\section{Developments of Postmodern Culture Theory and Music Culture}

Folk music, as an intangible cultural heritage, is an artistic language extracted by people in their working life [1]. The lyrics contain rich life knowledge, scientific and historical knowledge, and life perception. It's the eulogize of life and the pursuit of beautiful things. It's a positive expression of optimism and a manifestation of good character. This is consistent with the training and shaping direction of talents in any era. It accords with the guideline of modern education in China, and has important educational function for young generation. The intangible cultural heritage of folk music heritage education, the goal is not only to let the younger generation in vivid, vivid music language vividly understand its cultural traditions, increase the sense of national pride, to love country, love the people's educational purpose; to nurture the students' sentiment, improve students' aesthetic the perception and culture of the ethnic roots of the next generation, educational role cannot be ignored and far-reaching significance. Any kind of art education, its purpose is through the existing works, lead the students to realize the beauty in art, to form a good personal character, at the same time in the inheritance process, students will also carry on the deconstruction and re interpretation of this positive thinking, itself is beneficial to students' mind the development of. The original dance or composing technique works from the music language, in the understanding of works agglutination of aesthetic consciousness and national spirit, can make people gradually accumulated into their own self-cultivation, and ultimately the formation of national psychology and personality, and this is also the basis of our national spirit. On the other hand, the national aesthetic and sense of expression contained in the works also contain understanding of nature and life, which is rich in philosophy and wisdom.

A historical review of the postmodern cultural theory. After the modern culture, also known as postmodernism, postindustrial society culture, social culture, advanced culture, developed or transnational capital period after the capitalist culture, refers to the rise in the United States, quickly swept the whole western developed industrial society and an international rapid penetration to other areas the world's social and cultural trends. Therefore, the birth of postmodern culture theory has been born with a distinctive and unique color. Its radicalism and excellence has aroused academic scholars' research and discussion. At the same time, it also caused a strong repercussion, and the three words of "post-modern" became the most dazzling names of the academic world. However, in the 80 and 90s of twentieth Century, another peak was formed, which was a reflection on the debate. Since the birth of postmodernism, more questions have been raised about postmodernism. Scholars have discussed the modernity and rationality of postmodernism. The voice of opposition is getting more and more, and scholars have to reflect on whether their theories are dialectical and unified enough [2].

A brief description of the development view of post-modern music culture. In the middle of the 20 world, great changes have taken place in the development of music and culture in the world. Because 
the footsteps of the development of music culture gradually moved from modern mosaicism to the period of post-modern music culture. From the subject, the former is inclined to sensibility, and the latter is inclined to reason. Therefore, the emergence of post-modern music culture is not just about the art itself, but is more deeply felt. Art belongs to the category of ideology, and its role in the field of human spirit determines that it must be derived from life and higher than life. The weakness of the postmodernist music is that it is too equal to life. It is a kind of art that has lost the spiritual transcendental value.

The general situation of postmodern vocal performance art. Twentieth Century is a disaster era for the whole world [3]. The two world wars that continue to take place have a deep impact on the people of the world. It not only destroyed the rational order of mankind for thousands of years, but also trampled the spiritual home of mankind. The people stand in the face of traditional art, and the elegance and perfection of the past seem dull and incapable of helping people to reestablish their beliefs. The noise and frenzied rhythm of the postmodernist music seemed to be more adaptable to the vacant mood after the war. It refers to the depth loss of the aesthetic meaning of the works, which cannot be explained and can only be experienced. The traditional music and modern music works after the difference is that the former can be through the construction of the form, dig out the connotation of the works, from the deep meaning; the latter is not only the pursuit of depth, expression of representation, not the outcome, only feel the process and participation.

\section{Chinese Vocal Performance Art in the Process of Modernization}

Since vocal art as an independent artistic performance, the creation and singer's recreation of vocal creators is just like the two step of a technological process. The aesthetic concept of philosophy is called respecting history and creating future. The creation of the creators of vocal music works needs to be realized and perfected by the singer's recreation. The re - creation of the singer needs to rely on and base the creative intention and connotation of the vocal music creator, which is the essential feature of the vocal performance art. The perfect vocal performance is like a train loaded with the desire, hope, and even the luxury of the performers, moving into a warm and solemn music hall. Show the combined sound generator in performing in front of an object is not for machine translation or musical notation, but with the basic mode to show the multidimensional space range, showing a variety of means of communication, the form of vocal music creators show original intention and performance, especially valuable is to show the spiritual world and the unique style of performers composite carrier the connotation of personality [4].

The expression form of vocal performance art. The original form. The creator of vocal works is based on his historical background, social environment and cultural atmosphere. He creates inspiration and inspiration based on his own world outlook, ideology, aesthetic taste, experience and comprehensive accumulation. This time should be called the original form of vocal music works, it is not yet the form of material, just thinking of the things of the category. Basic form. When the creator of a vocal work records the product of creative desire and creative inspiration in written and symbolic form, it should be called the basic form of vocal works, in fact, it is the process of constantly modifying and perfecting until the finalization process. It is already a material form. Although the basic form also has the development process from the primary to the advanced, it is basically the main body in the form of material existence. Transformation form. When the vocal performance artist is inspired by his artistic mission, he starts from the impulse of deciding the vocal music work to stage on the stage of art, until the real stage of the art stage is called the preparatory stage, which is the recreation stage we emphasize. It is the transformation form of vocal music works. Because the transformation form must inherit the original gene, and add the process and achievement of the vocal performance artist's creation, basically the activities of eating thoughts, consciousness, ideas, feelings and feelings. It includes the method of occurrence, the conception of the application of technical skills, the creativity of the form of the body and so on. It still belongs to the things in the ideological category, not in the form of material. Complete the form. When the artist of vocal music performance with vocal works of the creators of reproduction results show their intention and recreation of labor, 
with the performing arts to the successful completion of the vocal works, this time should be called the complete form of vocal music works. It exists in the form of material.

The aesthetic principles of vocal performance art. The unity of objective reality and subjective initiative. Blindly imitate and consciously learn is completely different, Chinese vocal performance for the future of art performers, even in the period of study should gradually establish a sense of self, to be good at according to their professional conditions, and learn from those who can contribute to the development of their singing, and the final goal is to create and reflect the personality of the artistic image, gradually formed its own style of singing. Because an outstanding singer can truly embark on the advanced field of vocal performance art only when he is faithful to the spirit of the original while giving full play to his creative personality and achieving the unity of objective reality and subjective initiative in vocal performance. The unity of the historical style and the taste of the times. At the same time, because the vocal performers and performances in aesthetics and artistic personality, aesthetic taste, taste the times are different, in the actual art performances and appreciation, on one hand, emphasis or emphasis on music in the process of acceptance history style performance, outstanding music era the spirit, although it is difficult to avoid, but it is useful. Because it is likely to lead to a variety of vocal performance style, and is conducive to the vocal performers to create personality and artistic features of the full play. The singing skills and the perfect artistic expression of the vocal performance art are two important aspects of the complex, which complement each other, mutual support and intersect. There is no artistic performance without the skill of performing art, like a flower shelf in the street. On the other hand, out of the artistic expression, the singing skills will lose the value of its existence, like an electric doll, who refuses to perform in a thousand miles. Therefore, the perfect unity of singing skills and artistic expression is another important aesthetic principle of vocal performance art. The unity of singing skills and artistic expression.

\section{Practice of Postmodern Music Culture in Chinese Vocal Art}

$\mathrm{Li} \mathrm{Si}$, a musical educator, evaluated postmodernism in the twenty-first session of the opening ceremony of the International Symposium World Congress in 1994. He said: the discourse of the postmodernists, the evaluation of the Western cultural concept has the role of questioning the validity of the reality today or in the future. Postmodernists regard modernism as a part of the European Enlightenment movement, which is marked by the meaning of human progress, seeking for democratic knowledge and building a stable and harmonious human society. Modernism is based on spiritual authority, superior art, science, culture and society. It believes in direct evolution, absolute truth, the planning of ideal social order, and standardization of knowledge and products. In contrast, postmodernism appreciates diversity and diversity, division, uncertainty, and a distrust of all universal or authoritative discourse. The significance of Li Si's speech is to criticize the values of the single European music center by postmodernism, and to form various new concepts of music, culture equality and world music in international music education. Based on the present China, we should absorb the excellent culture of all the nations of the world according to the traditional music culture of its own country. Nowadays, when the post modernism is coming, we should have a cultural strategy and response. We should think about the reason why some cultural products should be introduced into China according to their own situations and problems. At the same time, to maintain a high degree of sensitivity and insight into the situation and problems of our country. So, it is possible to keep up with the international trend in culture at the same time, the local culture mode of interest and attention in foreign countries, the local culture show a new look, to the world. Postmodernist music culture is of great practical significance to the development of western music culture and Chinese music culture.

In the decades of reform and opening up, in addition to the new Chinese economy, the people's material and spiritual life is becoming more and more abundant. At the same time, the western post-modern Craze: modern films, punk rock, hippie T-shirt, and calculators, laser disc also lunged, rooting firmly in Chinese land, rapid growth. However, due to the low level of education and culture 
of most of the people, the popularity of Chinese pop music works is low. So it blindly follows the fashion of Hong Kong, Taiwan and Europe and the pop music.

Through the phenomenon of pop music culture, we should pay attention to the problems it has caused in Chinese sound art. Pop music takes off by the wings of the cultural industry, but the cultural industry is facing a great danger to the music culture, that is to maintain a pure material level, which will have an impact on people's music values. Many people even think that the future of Chinese music is a path to the development of western music. It is still lacking enough psychological preparation and necessary research for the Chinese people to accept the postmodern culture and what to accept and abandon. Today, when we discuss the situation of pop music in mainland China, we must see the great impact of the international music and audio industry on mainland pop music, and the plight of Chinese pop music.

We take the American composer Tan Dun's Opera Qin Shihuang as an example to talk about the deficiency of the postmodern cultural view in the Chinese vocal art practice. Tan Dun in the creation of Qin Shihuang was dedicated to listen to Xi'an traditional opera singing, he thought not only singing skill, but also reflects the broad and profound ancient China, and also the Italy opera beautiful lyrical and romantic elements in the works to. The greatest advantage of this opera is the successful application of the author to the musical material of the national drama. But the creation of the script is not only a little far from the history, but also there is a certain dispute in the character and molding of the characters.

\section{Conclusions}

The postmodern culture is rising in China, with both external and internal needs. China's reform and opening up has really entered the transformation from industrialization to modern society, and people's lifestyle, thinking and value orientation have changed. However, postmodern culture helps to accelerate the process of democratization of the whole cultural undertakings, including the music culture and art, and further close the relationship between culture and reality. The concept of pluralistic music culture in China has a long history and splendid culture of the ancient oriental civilization. During the long historical process, people of all ethnic groups have formed rich and valuable cultural heritage with their wisdom and sweat through long-term social practice. The vocal art education in China is constantly improving, and the communication with advanced foreign countries is also deepened. In the future, Chinese vocal music art will go to a new level, and it will surely catch the eye of the world.

\section{References}

[1] Xu Dunguang. A Critique on Esthetic Modernity Thought under Postmodern Context—A Discussion on American Mu sic Education Philosophy in the 20th Century [J]. Studies in Foreign Education, 2009, 36(228): 62-66.

[2] Du Juanmei. Emotion Antecedence of Vocal Music Art [J]. Hundred Schools in Arts, 2016(S1): 304-305.

[3] Sun Kai. Alternative Art: The Postmodern Creation of the Works of Music Education [J]. Journal of Educational Science of Hunan Normal University, 2015, 14(4): 115-117+128.

[4] Wang Gesong. "Imagine” and the Application in the Practice of Vocal Art [J]. Art of Singing, 2017(6): 46-50. 